ISSN : 2622-6154 (print)

\title{
ANALISIS LOCATION QUOTIENT KOMODITAS CABAI DI KABUPATEN KEDIRI
}

\author{
Cynthia Paramita Astasari' ${ }^{1}$, Jabal Tarik Ibrahim², Harpowo ${ }^{3}$ \\ ${ }^{1}$ Program Studi Agribisnis, Fakultas Pertanian-Peternakan,Universitas Muhammadiyah Malang \\ ${ }^{2}$ Program Studi Agribisnis, Fakultas Pertanian-Peternakan Universitas Muhammadiyah Malang \\ ${ }^{3}$ Program Studi Agribisnis, Fakultas Pertanian-Peternakan Universitas Muhammadiyah Malang
}

email korespondensi: cynthiaparamita@yahoo.com

\begin{abstract}
Chili is vegetables that have an important role in agriculture in Indonesia. Generally, the amount of chili production is determined by the harvested area and productivity of the land. Chili is one of the main horticulture products in Indonesia. Kediri District is potential as a center of chili's production. According to Ibrahim, 2012 there are four major sub-district in the production of chili commodities, such as Kepung District, Puncu District, Papar District, and Pagu District. The determination of a commodity to be a superior commodity in Kediri District based on the consideration that not all vegetable commodities are suitable to be developed in all places. The purpose of this research is 1) Knowing the growth of chili's production, 2) Analyze the Location Quotient of chili in Kediri District, 3) Analyze the Location Quotient of cayenne in Kediri District. This research is using secondary data. This research data was analyzed by Location Quotient $(L Q)$. This research shows that the growth of harvested area has fluctuated every year. Chili's production has fluctuated during 2014-2016. Cayenne's production has fluctuated during 2014-2016. Mojo sub-district is basis area of harvested area and chili's production for last three years. Pagu District sub-district is basis area of harvested area and cayenne's production for last three years.
\end{abstract}

Keywords: Chili, Basis Sector, LQ Analysis

\section{INTISARI}

Cabai merupakan sayuran yang memiliki peran penting dalam pertanian di Indonesia. Umumnya jumlah produksi cabai ditentukan oleh luas panen dan produktivitas lahan (Ibrahim, 2012). Cabai merupakan salah satu produk hortikultura utama sektor pertanian di Indonesia. Kabupaten Kediri mempunyai potensi sebagai sentra produksi komoditas cabai. Menurut Ibrahim, 2012 ada empat wilayah unggulan dalam produksi komoditas cabai, yakni Kecamatan Kepung, Kecamatan Puncu, Kecamatan Papar, Kecamatan Pagu. Penetapan suatu komoditas menjadi komoditas unggulan di Kabupaten Kediri berdasarkan pertimbangan bahwa tidak semua komoditas sayuran cocok dikembangkan di semua tempat. Tujuan dari penelitian ini ialah 1) Mengetahui perkembangan komoditas cabai di Kabupaten Kediri, 2) Menganalisis Location Quotient cabai besar di Kabupaten Kediri, 3) Menganlisis Location Quotient komoditas cabai kecil di Kabupaten Kediri. Jenis penelitian ini yaitu deskriptif kuantitatif dengan menggunakan data sekunder. Metode analisis data yang digunakan yaitu menggunakan Analisis LQ (Location Quotient). Hasil penelitian menunjukkan bahwa perkembangan luas areal tanam komoditas cabai besar setiap tahunnya mengalami fluktuasi. Produksi komoditas cabai besar pada kurun waktu tiga tahun yakni pada tahun 2014-2016 cenderung mengalami fluktuasi. Produksi komoditas cabai kecil pada kurun waktu tiga tahun yakni pada tahun 2014-2016 cenderung mengalami fluktuasi Kecamatan Mojo merupakan wilayah basis untuk luas areal tanam dan produksi cabai besar selama tiga tahun berturutturut. Kecamatan Pagu merupakan wilayah basis untuk luas areal tanam dan produksi cabai kecil selama tiga tahun berturut-turut

Kata kunci: Cabai, Sektor Basis, Analisis LQ

\section{PENDAHULUAN}

Cabai merupakan sayuran yang memiliki peran penting dalam pertanian di Indonesia. Cabai dikonsumsi fresh maupun diolah dalam bentuk saos sambal atau pasta. Umumnya jumlah produksi cabai ditentukan oleh luas panen dan produktivitas lahan (Ibrahim, 2012). Cabai merupakan salah satu sayuran yang permintaannya cukup tinggi 
ISSN : 2622-6154 (print)

baik untuk pasar domestik maupun ekspor ke mancanegara, seperti Malaysia dan Singapura. Penduduk Indonesia sebagian besar mengonsumsi cabai dalam bentuk segar, kering dan olahan. Cabai merupakan salah satu produk hortikultura utama sektor pertanian di Indonesia. Produksi cabai merah nasional pada tahun 2012 mencapai 935.557 ton dimana terjadi kenaikan produksi sebesar 7,28\% dibandingkan tahun 2011 yang produksi cabainya sebesar 888.852 ton. Produksi cabai rawit nasional pada tahun 2012 mencapai 697.274 ton dimana produksi mengalami peningkatan sebesar 17,34\% (Kementrian Pertanian, 2015).

Kabupaten Kediri mempunyai potensi sebagai sentra produksi komoditas cabai. Menurut Ibrahim, 2012 ada empat wilayah unggulan dalam produksi komoditas cabai, yakni Kecamatan Kepung, Kecamatan Puncu, Kecamatan Papar, Kecamatan Pagu. Adanya wilayah dengan komoditas unggulan maka akan mempermudah untuk meningkatkan produktivitas komoditas cabai dan dapat mempermudah mengembangkan potensi wilayah tersebut agar dapat bersaing di pasar.

Komoditas unggulan adalah komoditas andalan yang memiliki posisi strategis, dimana berdasarkan pertimbangan teknis (kondisi tanah dan iklim) maupun sosial ekonomi dan kelembagaan (penguasaan teknologi, kemampuan sumberdaya manusia, infrastruktur, dan kondisi sosial budaya setempat) layak untuk dikembangkan di suatu wilayah (Badan Litbang Pertanian, 2003). Komoditas unggulan di Kabupaten Kediri ditetapkan berdasarkan pertimbangan bahwa tidak semua komoditas sayuran cocok dikembangkan di semua tempat.

Setiap tempat atau wilayah memiliki keunggulan tertentu karena kekhasan wilayahnya. Komoditas sayuran yang dikembangkan merupakan komoditas spesifik yang sesuai dengan kekhasan wilayah tersebut, sehingga diharapkan komoditas sayuran tersebut dapat bersaing baik di pasar regional, nasional, maupun internasional. Keuntungan memiliki komoditas unggulan yakni dapat menjadi sektor basis yang dapat mengekspor produknya ke luar wilayahnya.

Penelitian ini bertujuan untuk mengetahui, perkembangan komoditas di Kabupaten Kediri, kecamatan yang menjadi sektor basis dan non basis luas areal tanam cabai besar dan cabai kecil, kecamatan yang menjadi sektor basis dan non basis produksi cabai besar dan cabai kecil, dan kecamatan yang menjadi sektor basis selama tiga tahun berturut-turut.

\section{METODE PENELITIAN}

\section{Jenis Penelitian}

Jenis penelitian yang digunakan yaitu deskriptif dengan pendekatan kuantitatif. Data yang digunakan dalam penelitian ini adalah data sekunder pada tahun 2014-2016. Data bersumber dari Dinas Pertanian dan Badan Pusat Statitik (BPS), dan sumber lain yaitu jurnal dan hasil-hasil penelitian dan kemudian diolah sesuai dengan model.

\section{Metode Penentuan Lokasi}

Penelitian Analisis Location Quotient (LQ) Komoditas Cabai di Kabupaten Kediri akan dilakukan di seluruh wilayah Kabupaten Kediri. Penetapan lokasi penelitian ini dilakukan secara purposive. 
ISSN : 2622-6154 (print)

\section{Metode Pengumpulan Data}

Data yang digunakan dalam penelitian ini adalah data sekunder pada tahun 20142016. Data bersumber dari Dinas Pertanian dan Badan Pusat Statitik (BPS), dan sumber lain yaitu jurnal dan hasil-hasil penelitian dan kemudian diolah sesuai dengan model. Data yang tercakup dalam penelitian ini adalah luasan produksi komoditas cabai (besar dan kecil) di seluruh kecamatan yang terdapat di Kabupaten Kediri tahun 2014-2016.

\section{Analisis Data}

\section{Location Quotient}

Penelitian ini menggunakan metode Location Quotient (LQ). Analisis ini digunakan untuk melihat suatu komoditas menjadi sektor basis atau non basis. Formula matematis untuk metode LQ adalah sebagai berikut :

Keterangan :

$$
\mathrm{LQ}=\frac{\text { pit }}{\text { Pit }}
$$

Pit $=$ share areal panen komoditas i pada tingkat wilayah $\mathrm{t}$

Pit $=$ share areal panen komoditas i pada tingkat Kabupaten.

Hasil perhitungan LQ menghasilkan tiga kriteria yaitu :

a. LQ > 1 : Komoditas itu menjadi basis atau sumber pertumbuhan. Komoditas memiliki keunggulan komparatif, hasilnya tidak saja dapat memenuhi kebutuhan di wilayah bersangkutan akan tetapi juga dapat diekspor ke luar wilayah.

b. LQ = 1 : Komoditas itu tergolong non basis, tidak memiliki keunggulan komaparatif. Produksinya hanya cukup untuk memenuhi kebutuhan wilayah sendiri dan tidak mampu untuk diekspor.

c. LQ $<1$ : Komoditas itu tergolong non basis. Produksi komoditas di suatu wilayah tidak dapat memenuhi kebutuhan sendiri sehingga perlu pasokan dari luar atau impor.

\section{HASIL DAN PEMBAHASAN}

\section{Perkembangan Produksi Cabai}

Perkembangan komoditas cabai besar di Kabupaten Kediri dapat dilihat dari perkembangan luas areal dan jumlah produksi cabai besar. Kabupaten Kediri terbagi menjadi 26 kecamatan yang rata-rata memproduksi cabai besar sebagai komoditas unggulanmya.

\section{a. Perkembangan Luas Areal Tanam Cabai Besar Tahun 2014-2016}

Perkembangan luas areal panen komoditas cabai besar di Kabupaten Kediri secara umum pada periode tahun 2014-2016 atau tiga tahun berturut turut mengalami fluktuasi. Peningkatan luas panen dapat disebabkan karena harga cabai yang cukup menjanjikan dan dibutuhkan oleh masyarakat secara luas sedangkan penurunan luas areal tanam disebabkan adanya pengaruh iklim dan cuaca serta adanya alih fungsi lahan yang dapat mengurangi lahan pertanian. 


\section{JOURNAL AGRIECOBIS}

ISSN : 2621-3974 (online)

Volume 01, Number 02 (2018)

ISSN : 2622-6154 (print)

Tabel 1. Luas Areal Tanam Cabai Besar Tahun 2014-2016

\begin{tabular}{|c|c|c|c|c|}
\hline \multirow[t]{2}{*}{ No. } & \multirow[t]{2}{*}{ Kecamatan } & \multicolumn{3}{|c|}{ Luas Lahan (Ha) } \\
\hline & & 2014 & 2015 & 2016 \\
\hline 1. & Gampengrejo & 3 & 3 & 5 \\
\hline 2. & Grogol & 0 & 0 & 0 \\
\hline 3. & Mojo & 19 & 11 & 11 \\
\hline 4. & Semen & 3 & 5 & 4 \\
\hline 5. & Tarokan & 0 & 0 & 0 \\
\hline 6. & Ngadiluwih & 20 & 13 & 4 \\
\hline 7. & Kras & 0 & 8 & 6 \\
\hline 8. & Kandat & 16 & 14 & 10 \\
\hline 9. & Wates & 80 & 74 & 55 \\
\hline 10. & Ngancar & 79 & 53 & 109 \\
\hline 11. & Pare & 14 & 5 & 2 \\
\hline 12. & Kandangan & 24 & 20 & 14 \\
\hline 13. & Kepung & 450 & 645 & 432 \\
\hline 14. & Puncu & 6 & 0 & 0 \\
\hline 15. & Gurah & 0 & 1 & 25 \\
\hline 16. & Plosoklaten & 0 & 0 & 0 \\
\hline 17. & Papar & 21 & 19 & 14 \\
\hline 18. & Plemahan & 11 & 5 & 3 \\
\hline 19. & Pagu & 1 & 0 & 0 \\
\hline 20. & Purwoasri & 6 & 1 & 0 \\
\hline 21. & Kunjang & 16 & 6 & 12 \\
\hline 22. & Banyakan & 8 & 5 & 7 \\
\hline 23. & Ringinrejo & 19 & 8 & 3 \\
\hline 24. & Kayenkidul & 3 & 8 & 0 \\
\hline 25. & Badas & 18 & 4 & 11 \\
\hline 26. & Ngasem & 0 & 2 & 0 \\
\hline & & 817 & 910 & 727 \\
\hline
\end{tabular}

Berdasarkan Tabel 1, luas areal tanam cabai besar selama tiga tahun berturut-turut yakni dari tahun 2014 sampai dengan 2016 mengalami fluktuasi. Mulai tahun 2014 luas areal tanam cabai besar sebesar 817 hektar, lalu meningkat menjadi 910 hektar pada 2015. Pada 2016 luas areal tanam cabai besar mengalami penurunan yang signifikan sebesar 727 hektar. Peningkatan secara signifikan terjadi pada 2015 sebesar 910 hektar.

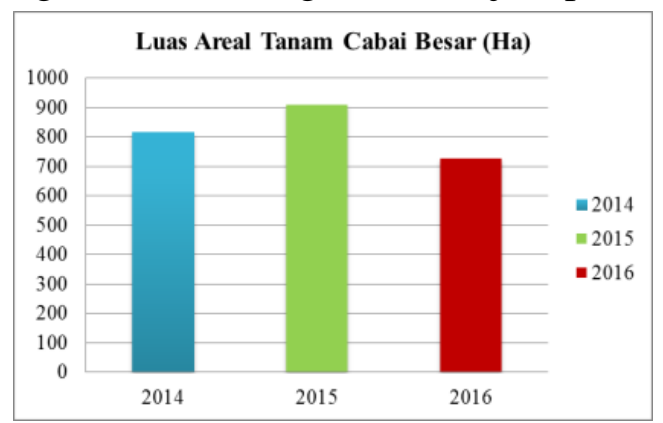

Sumber : Data Sekunder diolah, 2017

Gambar 1. Luas Areal Tanam Cabai Besar Tahun 2014-2016 
ISSN : 2622-6154 (print)

Gambar 1 adalah diagram yang menunjukkan perkembangan luas areal tanam cabai besar dari tahun 2014 sampai dengan 2016. Diagram ini menunjukkan fluktuasi perkembangan luas areal tanam cabai besar. Pada tahun 2014 luas areal tanam sebesar 817 hektar, tahun 2015910 hektar, dan tahun 2016727 hektar.

\section{b. Perkembangan Produksi Cabai Besar Tahun 2014-2016}

Produksi komoditas cabai besar pada kurun waktu tiga tahun yakni pada tahun 2014-2015 cenderung mengalami fluktuasi. Fluktuasi ini cenderung mengalami kenaikan setiap tahunnya selama tiga tahun berturut turut. Pada tahun 2014 produksi cabai besar di Kabupaten Kediri adalah sebesar 29.424 kuintal, selanjutnya pada tahun 2015 produksi cabai besar yaitu sebesar 25.505 kuintal artinya pada tahun 2015 produksi cabai besar mengalami penurunan. Pada tahun 2016 produksi cabai besar mengalami peningkatan yang cukup signifikan yakni sebesar 67.374 kuintal.

Tabel 2. Perkembangan Produksi Cabai Besar Tahun 2014-2016

\begin{tabular}{llccc}
\hline No. & \multicolumn{3}{c}{ Kecamatan } & \multicolumn{3}{c}{ Produksi $\mathbf{K u})$} \\
\cline { 3 - 5 } & & $\mathbf{2 0 1 4}$ & $\mathbf{2 0 1 5}$ & $\mathbf{2 0 1 6}$ \\
\hline 1. & Gampengrejo & 295 & 220 & 300 \\
2. & Grogol & 0 & 0 & 0 \\
3. & Mojo & 843 & 515 & 599 \\
4. & Semen & 345 & 316 & 266 \\
5. & Tarokan & 0 & 0 & 0 \\
6. & Ngadiluwih & 1.698 & 864 & 56 \\
7. & Kras & 0 & 142 & 80 \\
8. & Kandat & 899 & 1228 & 520 \\
9. & Wates & 3.963 & 4620 & 2.798 \\
10. & Ngancar & 3.096 & 4318 & 3.176 \\
11. & Pare & 770 & 440 & 126 \\
12. & Kandangan & 1.831 & 1475 & 1.325 \\
13. & Kepung & 8.697 & 5901 & 52.681 \\
14. & Puncu & 0 & 495 & 0 \\
15. & Gurah & 0 & 60 & 1.200 \\
16. & Plosoklaten & 0 & 0 & 0 \\
17. & Papar & 2.793 & 2228 & 2.023 \\
18. & Plemahan & 700 & 201 & 324 \\
19. & Pagu & 80 & 0 & 0 \\
20. & Purwoasri & 634 & 85 & 0 \\
21. & Kunjang & 673 & 597 & 603 \\
22. & Banyakan & 490 & 142 & 452 \\
23. & Ringinrejo & 607 & 705 & 207 \\
24. & Kayenkidul & 0 & 254 & 0 \\
25. & Badas & 1.010 & 699 & 638 \\
26. & Ngasem & 0 & 0 & 0 \\
\hline & & 29.424 & 25.505 & \\
\hline & & & & \\
\hline
\end{tabular}

Tabel 2 diketahui bahwa dari tahun 2014 sampai dengan tahun 2016 jumlah produksi yang terbesar adalah pada tahun 2016 yaitu sebesar 67.374 kuintal. Pada tahun 2014 produksi cabai besar sebesar 29.424 kuintal 1 lalu mengalami penurunan yang 
ISSN : 2622-6154 (print)

signifikan pada tahun 2015 sebesar 25.505 kuintal intal. Pada tahun 2016 produksi cabai besar mengalami peningkatan yang cukup signifikan sebesar 67.374 kuintal.

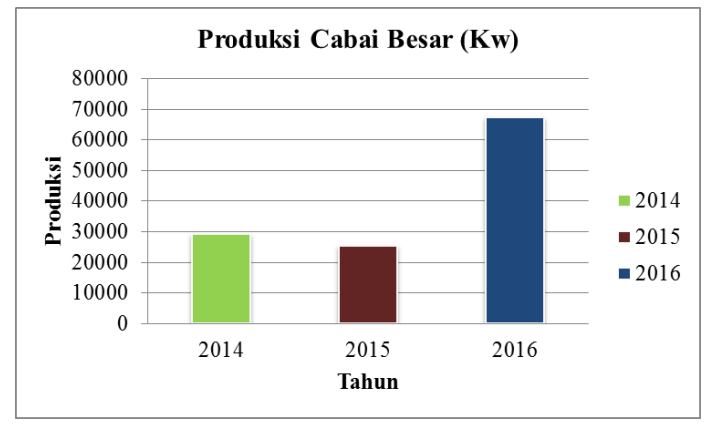

Sumber : Data Sekunder diolah, 2018

Gambar 2. Perkembangan Produksi Cabai Besar Tahun 2014-2016

Gambar 2 adalah diagram yang menunjukkan perkembangan produksi cabai besar selama tahun 2014-2016. Perkembangan yang terjadi sangat fluktuatif, tidak ada kecenderungan dalam hal peningkatan maupun penurunan. Produksi terendah cabai besar terjadi pada tahun 2015 yakni sebesar 25.505 kuintal. Produksi tertinggi cabai besar terjadi pada tahun 2016 yakni sebesar 67.374 kuintal.

\section{c. Perkembangan Luas Areal Tanam Cabai Kecil Tahun 2014-2016}

Perkembangan luas areal panen komoditas cabai kecil di Kabupaten Kediri secara umum pada periode tahun 2014-2016 atau tiga tahun berturut turut mengalami fluktuasi. Peningkatan luas panen dapat disebabkan karena harga cabai yang cukup menjanjikan dan dibutuhkan oleh masyarakat secara luas sedangkan penurunan luas areal tanam disebabkan adanya pengaruh iklim dan cuaca serta adanya alih fungsi lahan yang dapat mengurangi lahan pertanian. Peningkatan secara signifikan terjadi pada tahun 2014 sebesar 6.410 hektar.

Tabel 3. Perkembangan Luas Areal Tanam Cabai Kecil Tahun 2014-2016

\begin{tabular}{llrrr}
\hline \multirow{2}{*}{ No. Kecamatan } & \multicolumn{3}{c}{ Luas Lahan (Ha) } \\
\cline { 3 - 5 } & & $\mathbf{2 0 1 4}$ & $\mathbf{2 0 1 5}$ & $\mathbf{2 0 1 6}$ \\
\hline 1. & Gampengrejo & 20 & 5 & 5 \\
2. & Grogol & 0 & 0 & 0 \\
3. & Mojo & 7 & 13 & 11 \\
4. & Semen & 14 & 14 & 12 \\
5. & Tarokan & 0 & 0 & 0 \\
6. & Ngadiluwih & 25 & 6 & 0 \\
7. & Kras & 8 & 39 & 10 \\
8. & Kandat & 12 & 29 & 0 \\
9. & Wates & 57 & 49 & 96 \\
10. & Ngancar & 62 & 38 & 48 \\
11. & Pare & 19 & 20 & 27 \\
12. & Kandangan & 18 & 20 & 13 \\
13. & Kepung & 1.050 & 921 & 583 \\
14. & Puncu & 2.969 & 1.510 & 1.067 \\
15. & Gurah & 381 & 510 & 331 \\
16. & Plosoklaten & 363 & 368 & 360
\end{tabular}


ISSN : $\underline{2622-6154}$ (print)

\begin{tabular}{llrrr} 
17. & Papar & 25 & 32 & 35 \\
18. & Plemahan & 8 & 34 & 23 \\
19. & Pagu & 1.038 & 1.152 & 952 \\
20. & Purwoasri & 2 & 4 & 3 \\
21. & Kunjang & 3 & 1 & 0 \\
22. & Banyakan & 2 & 6 & 9 \\
23. & Ringinrejo & 8 & 81 & 5 \\
24. & Kayenkidul & 234 & 358 & 386 \\
25. & Badas & 6 & 3 & 4 \\
26. & Ngasem & 79 & 77 & 83 \\
\hline & & 6.410 & 5.290 & 4.063 \\
\hline
\end{tabular}

Sumber : Data Sekunder diolah, 2018

Tabel 3 menunjukkan bahwa luas areal tanam cabai kecil yang paling rendah terjadi pada tahun 2016 sebesar 4.063 hektar, sedangkan luas areal tanam yang paling besar terjadi pada tahun 2014 sebesar 6.410 hektar.

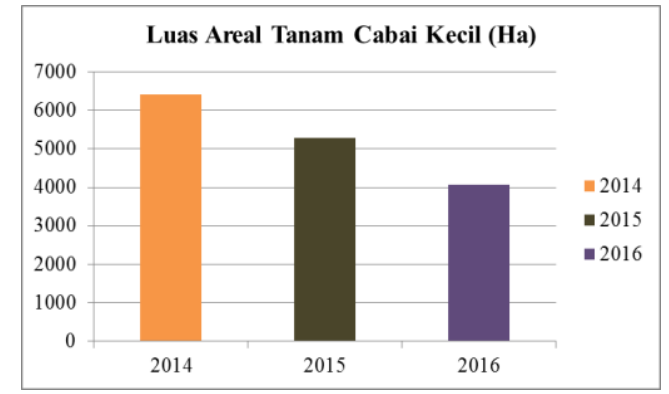

Sumber : Data Sekunder diolah, 2018

Gambar 3. Perkembangan Luas Areal Tanam Cabai Kecil Tahun 2014-2016

Gambar 3 menunjukkan perkembangan luas areal tanam cabai kecil. Luas areal tanam cabai kecil mengalami penurunan dari tahun 2014 sampai dengan 2016. Fluktuasi yang terjadi cenderung mengalami penurunan yang sangat signifikan.

\section{d. Perkembangan Produksi Cabai Kecil Tahun 2014-2016}

Produksi komoditas cabai kecil pada kurun waktu tiga tahun yakni pada tahun 2014-2015 cenderung mengalami fluktuasi. Produksi cabai kecil pada tahun 2014 di Kabupaten Kediri adalah sebesar 148.282 kuintal, selanjutnya pada tahun 2015 produksi cabai kecil yaitu sebesar 200.648 kuintal. Produksi cabai kecil pada tahun 2016 mengalami penurunan yang cukup signifikan yakni sebesar 181.274 kuintal.

Tabel 4. Perkembangan Produksi Cabai Kecil Tahun 2014-2016

\begin{tabular}{llccc}
\hline No. & Kecamatan & \multicolumn{3}{c}{ Produksi $(\mathbf{K u})$} \\
\cline { 3 - 5 } & & $\mathbf{2 0 1 4}$ & $\mathbf{2 0 1 5}$ & $\mathbf{2 0 1 6}$ \\
\hline 1. & Gampengrejo & 962 & 492 & 340 \\
2. & Grogol & 0 & 0 & 0 \\
3. & Mojo & 35 & 629 & 967 \\
4. & Semen & 714 & 660 & 502 \\
5. & Tarokan & 0 & 0 & 0 \\
6. & Ngadiluwih & 1.931 & 342 & 128 \\
7. & Kras & 318 & 217 & 494 \\
8. & Kandat & 110 & 924 & 532
\end{tabular}


ISSN : 2622-6154 (print)

\begin{tabular}{llccc} 
9. & Wates & 2.099 & 1.911 & 5.745 \\
10. & Ngancar & 1.119 & 1.875 & 1.601 \\
11. & Pare & 725 & 655 & 927 \\
12. & Kandangan & 985 & 1.270 & 1.030 \\
13. & Kepung & 6140 & 33.607 & 35.129 \\
14. & Puncu & 39.024 & 76.491 & 42.609 \\
15. & Gurah & 37.726 & 16.633 & 17.662 \\
16. & Plosoklaten & 5.540 & 10.825 & 4.588 \\
17. & Papar & 2.931 & 1.746 & 4.055 \\
18. & Plemahan & 35 & 5613 & 1761 \\
19. & Pagu & 40.678 & 34.726 & 45.968 \\
20. & Purwoasri & 619 & 387 & 120 \\
21. & Kunjang & 75 & 169 & 0 \\
22. & Banyakan & 175 & 293 & 477 \\
23. & Ringinrejo & 140 & 960 & 1.653 \\
24. & Kayenkidul & 3.993 & 6.906 & 12.523 \\
25. & Badas & 320 & 125 & 90 \\
26. & Ngasem & 1888 & 3192 & 2373 \\
\hline & & 148.282 & 200.648 & 181.274 \\
\hline
\end{tabular}

Sumber : Data Sekunder diolah, 2018

Tabel 4 menunjukkan bahwa perkembangan produksi cabai kecil di Kabupaten Kediri mengalami fluktiasi. Fluktuasi yang terjadi tidak ada kecenderungan peningkatan maupun penurunan. produksi cabai kecil pada tahun 2014 sebesar 148.282 kuintal. Pada tahun 2015 produksi cabai kecil sebesar 200.648 kuintal, artinya pada tahun 2015 produksi cabai kecil mengalami peningkatan yang signifikan. Produksi cabai kecil pada tahun 2016 mengalami penurunan kembali sebesar 181.274 kuintal.

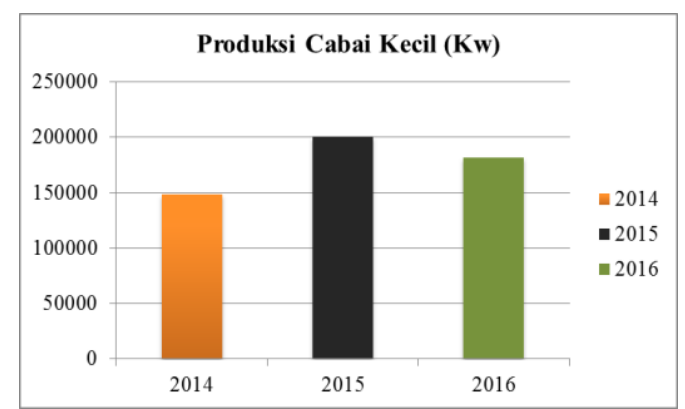

Sumber : Data Sekunder diolah, 2018

Gambar 4. Perkembangan Produksi Cabai Kecil Tahun 2014-2016

Gambar 4 merupakan diagram perkembangan produksi cabai kecil yang mengalami fluktuasi selama tiga tahun berturut-turut. Peningkatan yang cukup signifikan terjadi pada tahun 2015 yakni produksi cabai kecil sebesar 200.648 kuintal. Produksi terendah terjadi pada tahun 2014 sebesar 148.282 kuintal.

\section{Analisis Location Quotient Komoditas Cabai}

a. Wilayah Basis Luas Areal dan Produksi Cabai Besar

Wilayah basis dan non basis ditentukan oleh hasil LQ luas areal tanam dan produksi cabai besar. Tabel 5 merupakan hasil analisis LQ untuk luas areal tanam dan produksi cabai besar selama tiga tahun berturut-turut. Berdasarkan tabel 4.23 akan 
ISSN : 2622-6154 (print)

diketahui lima wilayah yang memiliki hasil LQ paling besar. Hasil analisis ini juga berguna untuk mengetahui wilayah mana saja yang memiliki LQ paling besar selama tiga tahun berturut-turut.

Tabel 5. LQ Luas Areal Tanam dan Produksi Cabai Besar

LQ Produksi

LQ Luas Areal Tanam

2015

LQ Luas Areal Tanam

2016
4,7(Ringinrejo)

4,4 (Banyakan)

3,1 (Kepung) 3,0 (Mojo)

2,9 (Kandat)

4,7(Ringinrejo)

5,7 (Banyakan)

3,5 (Kepung)

2,9 (Kandangan)

2,6 (Semen)

2,2 (Mojo)

4,7 (Mojo)

3,4 (Kepung)

2,6 (Wates)

2,1 (Ngancar)

1,7 (Kandat)

6,0 (Gampengrejo)

5,6 (Mojo)

3,2 (Wates)

2,8 (Ngancar)

2,8 (Kandangan)

5,9 (Mojo)

4,7 (Kandat)

3,1 (Gampengrejo)

3,0 (Ngancar)

3,0 (Kepung)

3,7 (Kepung)

2,5 (Mojo)

1,9 (Gampengrejo)

1,0 (Kandat)

1,0 (Kandangan)

Sumber : Data Sekunder diolah, 2018

Hasil analisis LQ produksi tanaman cabai besar pada tahun 2014 menunjukkan bahwa lima daerah yang memiliki nilai LQ paling besar adalah Kecamatan Banyakan, Kepung, Kandangan, Semen, dan Mojo. Pada tahun 2015 wilayah yang memiliki LQ paling besar yaitu Kecamatan Gampengrejo, Mojo, Wates, Ngancar, dan Kandangan. Pada tahun 2016 wilayah yang memiliki nilai LQ paling besar yaitu Kecamatan Kepung, Mojo, Gampengrejo, Kandat, dan Kandangan. Dapat disimpulkan bahwa wilayah yang selalu menjadi sektor basis yaitu Kecamatan Mojo. Kecamatan Mojo tidak hanya menjadi wilayah basis pada luas areal tanam saja tetapi juga menjadi wilayah basis pada produksi cabai besar.

Nilai LQ untuk luas areal tanam cabai besar di Kecamatan Mojo cenderung mengalami peningkatan. Peningkatan ini disebabkan karena luas lahan pertanian di 


$\begin{array}{ll} & \text { JOURNAL AGRIECOBIS } \\ \text { ISSN : } 2621-3974 \text { (online) } & \text { Volume 01, Number } 02 \text { (2018) } \\ \text { ISSN : } \underline{2622-6154} \text { (print) } & \end{array}$

Kecamatan Mojo selalu meningkat. Lahan yang ada di Kecamatan Mojo dikelola dengan baik oleh kelompok-kelompok tani yang ada di setiap desa. Kebijakan pemerintah juga berpengaruh dalam kegiatan pertanian yang ada di Kecamatan Mojo karena Kecamatan Mojo memiliki potensi luas lahan pertanian yang besar.

Nilai LQ untuk produksi cabai besar di Kecamatan Mojo cenderung fluktuatif. Kecamatan Mojo tidak selalu memiliki nilai LQ yang tinggi, tetapi selama tiga tahun berturut-turut Kecamatan Mojo selalu menjadi sektor basis untuk produksi cabai besar. Produksi cabai besar di Kecamatan Mojo selalu meningkat karena luas areal tanamnya yang juga selalu meningkat.

\section{b. Wilayah Basis Luas Areal dan Produksi Cabai Kecil}

Wilayah basis dan non basis ditentukan oleh hasil LQ luas areal tanam dan produksi cabai kecil. Tabel 6merupakan hasil analisis LQ untuk luas areal tanam dan produksi cabai kecil selama tiga tahun berturut-turut. Berdasarkan tabel 4.24 akan diketahui lima wilayah yang memiliki hasil LQ paling besar. Hasil analisis ini juga berguna untuk mengetahui wilayah mana saja yang memiliki LQ paling besar selama tiga tahun berturut-turut.

Tabel 6. LQ Luas Areal Tanam dan Produksi Cabai Besar

\begin{tabular}{|c|c|c|}
\hline \multirow{11}{*}{2014} & \multirow{6}{*}{ LQ Luas Areal Tanam } & $1,8($ Pagu $)$ \\
\hline & & 1,7 (Ngasem) \\
\hline & & 1,7 (Puncu) \\
\hline & & 1,5 (Kayenkidul) \\
\hline & & 1,2 (Plosoklaten) \\
\hline & & $1,8(\mathrm{Pagu})$ \\
\hline & \multirow{5}{*}{ LQ Produksi } & 3,9 (Pagu) \\
\hline & & 2,8 (Puncu) \\
\hline & & 2,6 (Gurah) \\
\hline & & 2,5 (Ngasem) \\
\hline & & 1,7 (Kayenkidul) \\
\hline \multirow{10}{*}{2015} & \multirow{5}{*}{ LQ Luas Areal Tanam } & $1,7(\mathrm{Pagu})$ \\
\hline & & 1,6 (Puncu) \\
\hline & & 1,5 (Kayenkidul) \\
\hline & & 1,5 (Gurah) \\
\hline & & 1,4 (Ngasem) \\
\hline & & 3,1 (Pagu) \\
\hline & \multirow{4}{*}{ LQ Produksi } & 2,5 (Gurah) \\
\hline & & 2,4 (Puncu) \\
\hline & & 2,1 (Ngasem) \\
\hline & & 1,7 (Gampengrejo) \\
\hline \multirow{9}{*}{2016} & \multirow{5}{*}{ LQ Luas Areal Tanam } & $2,0(\mathrm{Pagu})$ \\
\hline & & 2,0 (Kayenkidul) \\
\hline & & 1,9 (Gurah) \\
\hline & & 1,8 (Puncu) \\
\hline & & 1,6 (Ngasem) \\
\hline & \multirow{4}{*}{ LQ Produksi } & 3,1 (Gurah) \\
\hline & & 3,1 (Pagu) \\
\hline & & 2,7 (Kayenkidul) \\
\hline & & 2,3 (Puncu) \\
\hline
\end{tabular}


Sumber : Data Sekunder diolah, 2018

Hasil analisis LQ produksi tanaman cabai kecil pada tahun 2014 menunjukkan bahwa lima daerah yang memiliki nilai LQ paling besar adalah Kecamatan Pagu, Puncu, Gurah, Ngasem, dan Kayenkidul. Pada tahun 2015 wilayah yang memiliki LQ paling besar yaitu Kecamatan Pagu, Gurah, Puncu, Ngasem, dan Gampengrejo. Pada tahun 2016 wilayah yang memiliki nilai LQ paling besar yaitu Kecamatan Gurah, Pagu, Kayenkidul, Puncu, dan Mojo. Dapat disimpulkan bahwa wilayah yang selalu menjadi sektor basis yaitu Kecamatan Pagu, Puncu, dan Gurah. Kecamatan Pagu tidak hanya menjadi wilayah basis pada luas areal tanam saja tetapi juga menjadi wilayah basis pada produksi cabai besar.

Kecamatan Pagu, Puncu, dan Gurah merupakan sektor basis untuk luas areal tanam cabai kecil dan produksi cabai kecil. Hasil analisis nilai LQ menunjukkan bahwa selama tiga tahun berturut-turut tiga kecamatan tersebut selalu menjadi sektor basis walaupun nilainya yang fluktuatif. Kecamatan Pagu, Puncu dan Gurah memiliki komoditas unggulan yaitu cabai kecil, hal itu yang menyebabkan daerah tersebut selalu menjadi sektor basis. Keadaan tersebut juga didukung dengan adanya kelembagaan yang mendukung, inovatif, dan memadai. Adanya POSYANTEKDES juga merupakan salah satu yang mempengaruhi ketiga kecamatan tersebut menjadi sektor basis. POSYANTEKDES atau Pusat Informasi dan Pelayanan Teknologi Desa berfungsi untuk penerapan teknologi tepat guna. Program ini dapat membantu pengembangan usaha produksi produk unggulan di wilayah pedesaan dan sekaligus meningkatkan kesejahteraan masyarakat di desa.

\section{KESIMPULAN}

Berdasarkan pembahasan mengenai Analisis Location Quotient (LQ) Komoditas Cabai di Kabupaten Kediri, dapat disimpulkan bahwa perkembangan luas areal tanam komoditas cabai besar setiap tahunnya mengalami fluktuasi. Peningkatan luas panen dapat disebabkan karena harga cabai yang cukup menjanjikan dan dibutuhkan oleh masyarakat secara luas sedangkan penurunan luas areal tanam disebabkan adanya pengaruh iklim dan cuaca serta adanya alih fungsi lahan yang dapat mengurangi lahan pertanian. Peningkatan yang cukup signifikan terjadi pada tahun 2015 yaitu sebesar 910 hektar. Perkembangan luas area tanam komoditas cabai kecil setiap tahunnya mengalami fluktuasi. Peningkatan luas panen dapat disebabkan karena harga cabai yang cukup menjanjikan dan dibutuhkan oleh masyarakat secara luas sedangkan penurunan luas areal tanam disebabkan adanya pengaruh iklim dan cuaca serta adanya alih fungsi lahan yang dapat mengurangi lahan pertanian. Peningkatan yang cukup signifikan terjadi pada tahun 2014 yaitu sebesar 6.410 hektar. Produksi komoditas cabai besar pada kurun waktu tiga tahun yakni pada tahun 2014-2015 cenderung mengalami fluktuasi. Fluktuasi ini cenderung mengalami kenaikan setiap tahunnya selama tiga tahun berturut turut. Produksi komoditas cabai kecil pada kurun waktu tiga tahun yakni pada tahun 2014-2015 cenderung mengalami fluktuasi. Peningkatan dan penurunan produksi cabai dipengaruhi oleh harga cabai yang tidak stabil dan permintaan cabai untuk memenuhi kebutuhan rumah tangga maupun industri meningkat. Kecamatan Mojo merupakan wilayah basis untuk luas areal tanam dan produksi cabai besar selama 
ISSN : 2622-6154 (print)

tiga tahun berturut-turut. Kecamatan Pagu merupakan wilayah basis untuk luas areal tanam dan produksi cabai kecil selama tiga tahun berturut-turut

\section{DAFTAR PUSTAKA}

Azhar. 2001. Analisis Sektor Basis dan Non Basis di Provinsi Nanggroe Aceh Darussalam. , 1-9

Firdaus, Muhammad, et.al. 2009. Penentuan Komoditas Pertanian Unggulan Di Kabupaten Jember. Jurnal Sosial Ekonomi Pertanian 3(1):33-39.

Hendayana, Rachmat. 2003. Aplikasi Metode Location Quotient (LQ) Dalam Penentuan Komoditas Unggulan Nasional. Jurnal Informatika Pertanian 12:1-21.

Ibrahim, JT. 1995. Buku Diktat Metode Penelitian Sosial Ekonomi Pertanian. Malang: UMM.

Ibrahim, JT. 2012. Study on Market Appraisal and Value Chain Development Of Chilli Products In East Java. Riset Manajemen 0-52.

Kurniawan, Dicky. 2010. Alternatif Pengembangan Ekonomi Lokal Di Kota Pontianak Studi Kasus Pertanian Lidah Buaya. Kalimantan Barat. Jurnal Perencanaan dan Wilayah Kota. Vol. 21 No.1

Kurniawan, Rony. 2014. Aplikasi Location Quotient ( LQ ) Sebagai Metode Penentuan Komoditas Palawija Unggulan. Kediri. Jurnal Riset Ekonomi dan Bisnis. Vol 1 No. 2

Prajnanta, F. 2007. Agribisnis Cabai Hibrida. Jakarta: Penebar Swadaya

Raharjo, S., Widiatmaka, dan U.Sudadi. 2015. Analisis Kesesuaian Lahan Untuk Komoditas Sayuran Unggulan Di Kabupaten Batang. Jurnal Pengelolaan Sumberdaya Alam Dan Lingkungan 5(1):33-41

Sugiyono. 2010. Metode Penelitian Pendidikan Pendekatan Kuantitatif, kualitatif, dan $R \& D$. Bandung: Alfabeta

Suparman., 2006. Bercocok Tanam Cabai. Jakarta: Azka-Press

Suwandi. 2015. Outlook Cabai 2015. Pusat Data Dan Sistem Informasi Pertanian, 79

Tarigan, S dan W. Wiryanta., 2003 Bertanam Cabai Hibrida Secara Intensif. Jakarta : Agromedia Pustaka, , Hal : 16 - 17, 33, 90 - 92

Tindall, H. D., 1983. Vegetable In The Tropics. Mac Milan Press Ltd., London.

Yulianto, Dwi Puspita and Eko Budi Santoso. 2013. Identifikasi Potensi Komoditas Unggulan Pada Koridor Jalan Lintas Selatan Jatim Di Kabupaten TulungagungTrenggalek. Jurnal Teknik POMITS 2(2) 